\title{
Ovarian remnant syndrome in small animals
}

\section{Síndrome do ovário remanescente em pequenos animais}

\author{
Kellen de Sousa Oliveira ${ }^{1 *}$; Marco Augusto Machado Silva²; \\ Maurício Veloso Brun ${ }^{3}$; José Félix Pérez-Gutiérrez"; Gilson Hélio Toniollo ${ }^{5}$
}

\begin{abstract}
The ovarian remnant syndrome (ORS) is an iatrogenic disorder in bitches and queens, which is characterized by recurrence of estrus following surgical spay, due to the presence of a piece of ovarian tissue within the abdominal cavity. In most cases, the remnant ovary is found in the right ovarian pedicle, due to its topographic position, deeper and more cranial than the left ovary. The main clinical signs of ORS in small animals are the heat behavior and the presence of vaginal swelling/secretion, especially in canines. The diagnosis should be performed by means of vaginal cytology when attraction of males is detected, serum estrogen and progesterone levels and/or by challenging test with $\mathrm{GnRH}$ or hCG administration. However, vaginal citology is the most suitable and less expensive diagnostic tool. Nowadays the treatment of choice is a new laparotomy or laparoscopy, followed by removal of the remnant ovarian tissue. The surgical treatment has more chances of success if it is performed in the diestrus (i.e., between 15 and 60 days after the detection of attraction of males). Furthermore, a careful and accurate surgical procedure aided by advanced visualization techniques during ovariohysterectomy or ovariectomy is the best way to prevent ORS in companion animals.
\end{abstract}

Key words: Partial ovarian spay, recurrent estrus, bitches, queens

\section{Resumo}

A síndrome do ovário remanescente (SOR) é um distúrbio iatrogênico em cadelas e gatas caracterizado pelo retorno do estro após contracepção cirúrgica devido à presença de fragmento de tecido ovariano na cavidade abdominal. Frequentemente, o ovário remanescente está situado no pedículo ovariano direito, sobretudo devido a sua posição topográfica mais profunda e cranial em comparação ao ovário esquerdo. Os principais sinais clínicos de SOR em pequenos animais são cio e presença de edemaciamento/secreção vulvar/vaginal, especialmente em caninos. O diagnóstico deve ser realizado por meio de citologia vaginal quando detecta-se o interesse dos machos pela cópula com a fêmea acometida, dosagem sérica de estrógeno e progesterona e/ou por meio do teste provocativo com administração de GnRH ou hCG. Contudo, citologia vaginal constitui a opção de melhor custo-benefício para o diagnóstico. Atualmente, o tratamento de escolha é cirúrgico por meio de laparotomia exploratória ou laparoscopia, seguido pela remoção do ovário remanescente. $\mathrm{O}$ tratamento cirúrgico tem maiores taxas de sucesso quando realizado com o animal em diestro (i.e., entre 15 e 60 dias após detectada a atração dos machos). Ademais, a

\footnotetext{
${ }^{1}$ Pós-doutoranda pelo Programa de Pós-graduação em Medicina Veterinária, Faculdade de Ciências Agrárias e Veterinárias, Universidade Estadual Paulista "Júlio de Mesquita Filho", FCAV/UNESP, Jaboticabal, SP. E-mail: ksoliver13@hotmail.com

${ }^{2}$ Doutorando pelo Programa de Pós-graduação em Cirurgia Veterinária, FCAV/UNESP, Jaboticabal, SP. E-mail: silvamam@gmail. com

${ }^{3}$ Prof. do Centro de Ciências Rurais, Universidade Federal de Santa Maria, CCR/UFSM, Santa Maria, RS. E-mail: mauriciovelosobrun@hotmail.com

${ }^{4}$ Prof. da Universidad Complutense de Madrid, UCM, Madrid, Espanha. E-mail: jfperez@vet.ucm.es

${ }^{5}$ Prof. do Dept ${ }^{\circ}$ de Medicina Veterinária Preventiva e Reprodução Animal, FCAV/UNESP, Jaboticabal, SP. E-mail: toniollo@fcav. unesp.br

* Autor para correspondência
} 
realização de um procedimento cirúrgico preciso, auxiliado por técnicas avançadas de visualização durante a ovário-histerectomia ou ovariectomia constitui a melhor forma de prevenção SOR em animais de companhia.

Palavras-chave: Retirada parcial do ovário, castração, estro recorrente, cadelas, gatas

\section{Introduction}

The signs of estrus in small animals are the major reason for pet owners to seek veterinary advice. Suppression of estrus is frequently required in order to avoid vaginal bleeding, attraction of males, behavioural changes and undesired mating (VALLE; MARQUES JUNIOR, 1999).

Several methods of contraception and sterilization are available. Contraceptive methods are based on inhibiting the estral cycle by: hormonal treatments using progestins, androgens that act via negative feedback mechanisms or gonadotropin releasing hormone $(\mathrm{GnRH})$ analogs that block the Gnrh receptor; immunocontraception via vaccination against $\mathrm{GnRH}$, the luteinizing hormone (LH) receptor, sperm or zona pellucida proteins; disruption of fertility by using vaginal or intrauterine devices; intratesticular or intraepididymal injections; ultrasound testicular ablation or maintaining the animal permanently in anoestrus by means of surgical spay (EVANS; SUTTON, 1989, KUTZLER; WOODS, 2006).

Ovariohysterectomy (OHE) and ovariectomy (OVX) are the most commonly performed procedures for sterilization in small animal veterinary practice (EVANS; SUTTON, 1989; CONCANNON, 1995). Even though surgical spay is very efficient, it is not suitable if mating is required at some time. However, surgical contraception shows particular advantages, such as significant risk reduction of developing mammary neoplasms, especially when it is performed before the first estral cycle (CONCANNON; MEYERS-WALLEN, 1991). Additionally, OHE eliminates the risk of pyometra and reduces the incidence of pseudopregnancy and other studies have revealed increased longevity for neutered animals when compared to sexually intact animals (MICHELL, 1999; MOORE et al., 2001).
However, sterilization shows also some problems. Most of them caused by the decreased estrogen levels resulting from ovary removal such as urinary incontinence (MANDIGERS; NELL, 2001), obesity (RENAULD et al., 1984) and increased bone resorption (OURSLER et al., 1993). In addition, there can also be complications inherent to the surgical procedure such as: profuse bleeding, stump pyometra, uterine stump, draining fistulous tracts, eunuchoid syndrome, hydronefrosis/hydroureter following accidental ligature of the ureter, vesicovaginal and/or vaginoperitoneal fistulas, extra-luminal obstruction of the gastrointestinal tract due to postsurgical intraperitoneal adhesions and ovarian remnant syndrome (ORS) (HOLT, 1985; COOLMAN et al., 1999; STONE, 2003; GADELHA et al., 2004; RAGNI, 2005; HOLT; BOHANNON; DAY, 2006; SILVA, 2008).

A major problem that comes up after surgery is that pet owners return to the veterinarian because the animals regress to estrus a few weeks or even more than five years after surgical spay (MILLER, 1995; NELSON; COUTO, 2003). This is caused by the development of the ORS which is one of the most relevant long-term complications following OHE or OVX in small animals. Ovarian remnant syndrome is an iatrogenic disorder in companion animals, which results from unsuccessful surgical sterilization (PEARSON, 1973; WALLACE, 1991; MILLER, 1995; NELSON; COUTO, 2003). The presence of functional ovarian tissue within the abdominal cavity after surgical spay can impair the animal's life expectancy, as granulosa cell or mammary tumours may develop (SANGSTER, 2005; SOUZA et al., 2005).

This review describes and discusses various aspects related to the epidemiology, etiopathogeny and treatment of ORS in small animals. 


\section{Epidemiology and etiopathology}

Ovarian remnant syndrome has been described in small animals and in the woman (SHEMWELL; WEED, 1970; MCENTEE, 1990; WALLACE, 1991). In fact ORS apparently occurs more frequently in women than in female dogs and queens (WEBB, 1989; PRICE; EDWARDS; BUCHSBAUM, 1990; WALLACE, 1991).

In the bitch ORS may represent $16-43 \%$ of the long term complication following surgical spay (PEARSON, 1973; OKKENS; DIELEMAN; VAN DER GAAG, 1981). Pearson (1973) reported return to estrus and presence of ovarian tissue in 12 out of 72 bitches presenting at least one surgical complication following OHE. In a retrospective study, Okkens, Dieleman e Van Der Gaag (1981) found that 47 out of 109 bitches presenting complications after OHE were diagnosed with ORS and reoperated for resection of the remnant ovarian tissue.

The incidence of ORS has not been documented in the queen and its likely that many cases are not diagnosed since signs of estrus in queens with ORS may be more subtle compared to the bitch. On the other hand, some queens may show overt signs of estrus including vocalization, sexual receptivity, kneading and head rubbing (SHEMWELL; WEED, 1970). However, despite the signs of estrus are variable among queens a retrospective study found ORS to be more common in cats than in dogs (MILLER, 1995).

Ovarian remnant syndrome may occur due to the presence of ovarian tissue on the right, left or both arteriovenous ovarian complex (AVOC). The fragment of ovarian tissue may be present in both pedicles in approximately half of the cases (MILLER, 1995). However most of the authors have reported that remnant ovary is frequently found adhered to the right ovarian pedicle (OKKENS; DIELEMAN; VAN DER GAAG, 1981; WALLACE, 1991; PRATS, 2001; VAN GOETHEM; SCHAEFERSOKKENS; KIRPENSTEIJN, 2006). The most acceptable hypothesis for the frequent occurrence of remnant ovary on the right ovarian pedicle is based on the anatomical position of the right ovarian pedicle, which is deeper and more cranial than the left one in both canine and feline species (STONE, 2003; FOSSUM, 2007). Therefore, the exteriorization, ligature and resection of the right ovarian pedicle during the surgical procedure are more difficult, particularly in the bitch (PEARSON, 1973; WALLACE, 1991; MILLER, 1995; HEFFELFINGER, 2006; VAN GOETHEM; SCHAEFERS-OKKENS; KIRPENSTEIJN, 2006). Regarding the topography of the left ovarian pedicle, Silva (2008) observed that its anatomical position favoured the formation of intraperitoneal adhesions involving the left AVOC and bowel or mesentery at higher frequency than the right one in bitches following tradititional OHE. This information highlights the fact that the right ovarian pedicle is deeper than the left one, what may result in poor exposition during surgical spay.

There are basically three theories that explain the etiopathogeny of the ORS (FELDMAN; NELSON, 2004). The most accepted explanation is the incomplete surgical removal of one or both ovaries. Inadequate exposition of the ovaries (i.e., poor visualization of the pedicles due to small abdominal wall incision), improper positioning of the haemostatic clamps or ligatures and the AVOCs are the main surgical manoeuvres that may lead to incomplete resection of one or both ovaries (HOWE, 2006). In these cases, collateral neovascularization of the remnant ovary may occur, even if the haemostasis of the AVOCs was achieved (FINGLAND, 1998).

The second theory for the occurrence of ORS involves the accidental drop of a small fragment of ovarian tissue within the peritoneal cavity, immediately after de ovarian resection (HEFFELFINGER, 2006). The section of ovarian tissue may adhere to the mesometrium, greater omentum, parietal peritoneum, visceral serosa or mesometrium, regain vascularization and return to its normal function in a few weeks or months 
(PRATS，2001; FELDMAN; NELSON，2004; DENARDO et al., 2001).

This theory has been source of debate since as, actually, most case reports indicate the presence of remnant ovarian tissue on the AVOCs as the main cause of ORS (PERKINS; FRAZER, 1995). However, this etiopathogeny has been experimentally reproduced. Shemwell e Weed (1970) sutured a segment of autologous ovarian cortex graft to the parietal peritoneum of queens, which resulted in return to estrus. Denardo et al. (2001) dropped a free floating autologous ovarian mass within the abdominal cavity and verified revascularization of ovarian tissue adhered to the greater omentum or mesentery in cats following OHE. Davies (1990) attached autologous ovarian tissue to the subserosa layer of the greater gastric curvature or under the splenic capsule in bitches, which resulted in the return to estrus behaviour. The events that could lead to the formation of abdominal adhesions are not known but the activity of fibrin may be involved. Drollette e Badawy (1992) have shown that, under isquemic conditions, the normal fibrinolytic activity is suppressed. In addition, as the result of the insult to peritoneal surfaces caused by surgical manipulation, the concentrations of leukotriene B4 and prostaglandin E2 in the peritoneal fluid were increased while plasminogen activity is decreased, which leaded to the formation of fibrin deposits. The active fibrin may facilitate the adhesion of an accidental dropped piece of ovarian tissue (DROLLETTE; BADAWY, 1992).

The third possible cause of ORS is based on the presence of accessory ovarian tissue or supernumerary ovaries. This condition has been reported in the women, cattle and small animals (MCENTEE, 1990; STONE, 2003; MACHADO et al., 2008; TEMIZ et al., 2008). Accessory ovarian tissue grows from a primodium apart from the main gonad, may extend along the broad ligament or ovarian pedicle and is adjacent, though frequently connected to the main ovary and sharing common vascularization (MCENTEE, 1990). A poor visualization of the pedicles could impede accessory ovarian tissue removal which may become functional when the main gonads are removed and thus could be a possible cause of ORS.

However, despite the importance of a good visualization, ORS does not appear more frequent in animals in which the surgical procedure is particularly difficult, such as large, giant or deepchested breeds, like American Pit-bull, Rottweiler, Grand Danois and Labrador Retriver, which have some anatomical features, such as deeper localization of the pedicles, that may impede good visualization and favour to the development of ORS (WALLACE, 1991). In a similar manner, ORS has not shown higher frequency breeds prone to obesity, such as Labrador Retrievers, Golden Retrievers, Beagles, Weimaraners, Dalmatians, Basset Hounds, Shetland Sheepdogs, Mastiffs, St. Bernards, Cocker Spaniels, Dachshunds, Miniature Schnauzers, Miniature Poodles and Cairn Terrier; nonetheless, in our experience and in a previous study (SILVA, 2008) we found that the excess of fat tissue on the mesometrium and ovarian bursa comprises the identification and delimitation of the ovarian tissue.

Other factors, such as the experience of the surgeon, the surgical technique employed, condition of the patient (pregnancy, pyometra or salpingitis), which could contribute to the occurrence of ORS, have not been associated to the presentation of this syndrome (MILLER, 1995; VAN GOETHEM; SCHAEFERS-OKKENS; KIRPENSTEIJN, 2006). However, the age at which the animal was spayed could have some influence, as ORS has not been described in animals spayed at a younger age than 4 months (OURSLER et al., 1993; MILLER, 1995).

\section{Diagnosis}

Diagnosis of ORS is based on the detection of ovarian tissue that remains hormonally functional. Symptoms of estrus behaviour on an OHE animal lead to the suspicion of ORS, thus diagnosis relies on the anamnesis and the clinical history and has 
to be further confirmed by means of laboratory diagnostic procedures such as vaginal cytology, hormonal analysis and/or exploratory laparotomy with biopsy (PRATS, 2001; ROMAGNOLI, 2004).

Bitches suffering from ORS are usually taken back to the veterinarian after weeks, months or even years of surgical spay under signs of proestrus, estrus and occasionally pseudo pregnancy. Signs compatible with the presence of remnant ovarian tissue that has regain its functional capability include: proestral bleeding, estrus behaviour (standing and attraction of male dogs), vulvar enlargement, vulvar oedema, vulvar discharge that varies from red brown to white, vulvar licking, frequent urination, occasional mammary gland enlargement and milk production (CONCANNON, 1995; SANGSTER, 2005; HOWE, 2006).

In the cat, behavioural signs of estrus such as abnormal and frequent vocalization, affectionate head rubbing to owners, rolling, treading, lordosis, nymphomania, tail deviation, and attraction of toms have been described (NELSON; COUTO, 2003, HEFFELFINGER, 2006). However not all the queens that present ORS show overt behavioural signs of estrus (OURSLER et al., 1993; ENGLAND, 1997). Vaginal discharges and accumulation of secretion on the perineal area are uncommon in the cat, though there may be episodes of frequent urination (OURSLER et al., 1993).

In spite of the clinical signs associated to the estrus behaviour the diagnosis of ORS is not an easy task since the manifestation of this behaviour is not always clear and may depend on the amount of functional tissue within the abdominal cavity (FELDMAN; NELSON, 2004). Anamnesis should be carefully performed in order to rule out the possibility that the animal is under estrogen treatment, frequently prescribed for the control of urinary incontinence following spay (MANDIGERS; NELL, 2001); or to discard vaginitis or other alterations that may cause vulvar discharge (SONTAS; GÜRBULAK; EKICI, 2007).
Vaginoscopy can be a useful tool for the diagnosis of ORS. A "cobblestone appearance" of the vaginal mucosa is usually visualized during proestrus. This appearance is due to the presence of blood in the inner vaginal wall that could be a consequence of high estrogen levels. Estrogens act as vasodilators and increase vascular permeability, though the increment in nitric oxide (NO) production or modulation of calcium homeostasis in the vascular endothelium, of the well vascularizaed vagina of the bitch (SUZUKI et al., 2003). Thus the presence of sanguinolent secretion without concomitant penetrating/perforating lesions, trauma, uterine stump pyometra or neoplasic-like masses may be indicative of functional ovarian tissue in the neutered animal (SANGSTER, 2005).

However the best way to confirm ovarian activity is by vaginal cytology. Estrogen activity can be revealed during proestrus by the increased numbers of white cells and blood cells due to increased vascular permeability (JOHNSTON; KUSTRITZ; OLSON, 2001, SUZUKI et al., 2003). In addition proesturs cytology is characterized by the decreased number of basal and parabasal cells, and increased numbers of large intermediate and superficial cells. These cells can be easily recognized: basal and parabasal cells are round to oval shaped and have normal appearing large nucleus; large intermediate cells present a smooth oval rounded shape and nuclei generally smaller than in parabasal cells; superficial cells are large epithelial cells with irregular or angulated borders and a small nucleus that can be dark and pyknotic, faint or not distinguishable from the adjacent cytoplasm (JOHNSTON; KUSTRITZ; OLSON, 2001; SUZUKI et al., 2003).

The cell indicators of estrogen activity change during estrus. Actually vaginal cytological evaluation should be performed, if possible, during behavioural estrus, because at this stage the presence of $80 \%-90 \%$ of superficial cells are considered a solid evidence of ovarian activity (OURSLER et al., 1993, JOHNSTON; KUSTRITZ; OLSON, 2001). During estrus the serum estrogen levels decrease 
and the progesterone levels raise as the result of the incipient lutenization that follicular cells experience before the LH surge (CONCANNON; HANSEL; VISEK, 1975). The declining concentrations of estradiol along with the increasing progesterone levels may be necessary for estrus behaviour and initiating the LH surge in the bitch (CONCANNON; COWAN; HANSEL, 1979). As the result of the declining estrogen levels the vascular permeability and the number of erythrocyte and neutrophils diminish. However, the biological effects on vaginal cells remain for a longer period of time, allowing to detect at estrus a high proportion of superficial cells that were induced at proestrus. The presence of superficial cells during estrus is due to the hyperplasic estrogenic effects. Under the influence of estrogen, the thickness of the vaginal epithelium increases from a few layers during anoestrous to 2030 at the end of proestrus, increasing the distance from the vaginal capillaries to the superficial layers, which could prevent the access of survival signals and explain morphological characteristics of the superfical cells, such as cornification, nuclear shrinkage and piknosis that are related to cell death (IGUCHIL, 1996).

In the queen, vaginal cytological changes are more subtle than in the bitch. Erythrocytes and leucocytes are rarely seen since its vagina is less vascularized and during estrus or proestrus the number of neutrophils is 4.7 per 100 epithelial cells (MILLS; VALLI; LUMSDEN, 1979). A study performed in 20 estrous queens reported the following percentages: superficial nucleated cells (63.6), enucleated superficial cells (24.5), intermediate cells (11.6) and parabasal cells (0.3) (MILLS; VALLI; LUMSDEN, 1979). Following behavioural estrous the queens showed an increase in parabasal cells and a decrease in superficial cells. On the other hand, cats in anoestrus consisistenly exfoliated intermediate epithelial cells with only rare parabasal cells (JOHNSTON; KUSTRITZ; OLSON, 2001). As previously recommended for the bitch, cytology evaluation for the diagnosis of ORS should preferably be performed during behavioural estrous.

The levels of ovarian steroids, estradiol and progesterone can be measured in order to determine the presence of ovarian tissue. Serum estradiol over $10 \mathrm{pg} / \mathrm{mL}$ or serum progesterone over $0.2 \mathrm{ng} / \mathrm{mL}$ is indicative of ovarian activity in the bitch. Wallace (1991) assured that progesterone measurements are more specific to diagnose ORS than serum concentration of estradiol, because the ovary is the only source of progesterone in bitches. This author also recommended that these hormone assays should be performed few days after the end of the clinical signs inherent to proestrus or estrus.

Basal levels in OHE for estradiol in cats are less than $8 \mathrm{pg} / \mathrm{mL}$ and progesterone should not be detected (JOHNSTON; KUSTRITZ; OLSON, 2001, FELDMAN; NELSON, 2004).

Hormone challenge, also known as stimulation or provocative progesterone test is another interesting assessment for the diagnosis of ORS. This test is based on the administration of gonadotropin releasing hormone $(\mathrm{GnRH})$ or the human chorionic gonadotropin (hCG), an evolutionary counterpart of the luteinizing hormone (LH), during the follicular phase: during this phase these hormones will induce ovulation in both the bitch and the queen, leading to the corpus luteum formation and to a rise in progesterone levels that can be measured one or two weeks after the induction of ovulation (SONTAS; GÜRBULAK; EKICI, 2007).

One protocol applied to the bitch consist on inducing the ovulation with gonadotropin releasing hormone (GnRH, $2.2 \mu \mathrm{g} / \mathrm{kg}$, IM) or human chorionic gonadotropin (hCG, $50 \mathrm{IU} / \mathrm{kg}, \mathrm{IM}$ ) and measuring the progesterone levels before and after one or two weeks of the treatment (PRATS, 2001; ROMAGNOLI, 2004; SONTAS; GÜRBULAK; EKICI, 2007). If functional ovarian tissue is present within the abdominal cavity, the serum levels of estradiol will decrease, while the level of progesterone will increase following the provocative 
test (PERKINS; FRAZER, 1995; PRATS, 2001; FELDMAN; NELSON, 2004). However in the intact bitch, the administration of GnRH during anoestrous raises the plasma concentration of $\mathrm{LH}$ and estradiol; being the response of LH and estradiol to GnRH stimuli is higher in the late phase than in early phase of anoestrus (VAN HAAFTEN et al., 1994).

In cats the provocative test with GnRH (25 $\mu \mathrm{g}, \mathrm{IM})$ should be performed even in the case that vaginal cytology indicates estrogenic activity or even if the serum levels of estradiol are increased. The confirmation of ovulation may be achieved if estrogen levels are low (around $10 \mathrm{pg} / \mathrm{mL}$ ) and progesterone levels are high (over $1 \mathrm{ng} / \mathrm{mL}$ ) (PINEDA; DOOLEY, 2003; REECE; SWENSON; REECE, 2004; HEFFELFINGER, 2006).

Among the laboratory diagnostic procedures vaginal cytology is considered the least expensive, the quickest and the most simple and efficient method to diagnose ORS (SONTAS; GÜRBULAK; EKICI, 2007). In addition one advantage of the bioassay is that they reveal estrogenic influence for a longer period of time than the serum hormone determination. The levels serum of steroid can fluctuate rapidly while their biological effects remain for a longer period of time (WALLACE, 1991). In this regard Shille e Olson (1989) remark that the vaginal cytology evaluation as a bioassay for estrogen activity is more reliable than a single serum estradiol determination and for instance if the vaginal cytology evaluation is performed during estrus behaviour and the estrogen levels are low the veterinarian might incorrectly assume that this behaviour was not related to ovarian activity (WALLACE, 1991).
Additionally, fragments of ovarian tissue can be detected by ultrasonography, laparoscopy or exploratory laparotomy (BECK et al., 2004; SONTAS; GÜRBULAK; EKICI, 2007). In contrast to some reports in human medicine (PETTIT; LEE, 1988) ultrasonography is a poor diagnostic tool in small animals with remnant ovary. Because in our experience, a very small ovarian mass that can not to be detected by ultrasonography, is enough to promote ORS in many cases particularly in small size breeds. Nevertheless, Sontas, Gürbulak e Ekici (2007) reported a case of a Golden Retriever bitch that had been showing estrus every 5-6 monthintervals since it was ovariohysterectomized, for two years before readmission, and was diagnosed with a remnant ovary with several follicles by ultrasonography on the right side. These authors also suggest that this imaging tool may be useful on the diagnosis of ORS in large breed dogs.

The remnant ovarian tissue is more likely to be found when exploratory laparotomy is performed during the ovarian luteal phase, due to the presence of corpus luteum. The ovarian fragment is usually found in one or both ovarian pedicles (Fig. 1), adhered to the abdominal wall, greater omentum, visceral serosa or mesentery (BECK et al., 2004; HEFFELFINGER, 2006). The excised tissue should be placed in formalin $10 \%$ buffered solution and sent to microscopic anatomopathological investigation in order to confirm the presence of ovarian structures, especially when suspicious fragments are very small. The microscopic assessment may also reveal neoplasic disease of the remnant ovary, mainly granulosa cell tumors, even if clinical signs are absent (SIVACOLUNDHU; O'HARA; READ, 2001; SOUZA et al., 2005). 
Figure. 1. (A) Stump piometra (SP) in a Labrator Retriever suffering from ORS: firm fibrous adhesions (black arrow) are seen involving the uterine stump (SP), an intestinal loop (IL) and the mesenterium (ME). (B) Stump piometra in a Poodle with ORS: the uterine stump (US) is strongly attached (black arrow) to the bladder (BL).

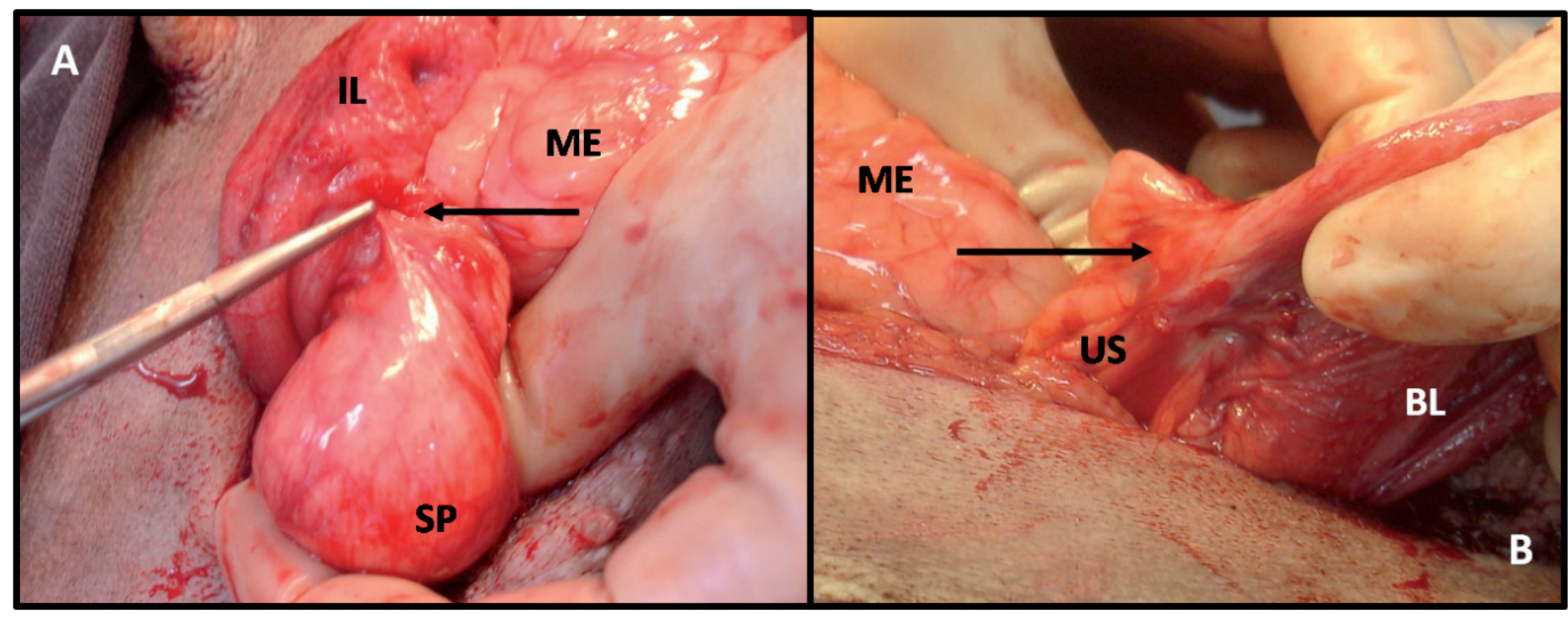

Fonte: VOORWALD, F. A. (2012)

\section{Differential diagnosis}

The ORS should be differentiated form other abnormalities that promote vaginal bleeding in spayed bitches and cats, including vaginal neoplasms, vaginitis, stump pyometra, penetrating vaginal traumatisms, treatment with exogenous estrogen and coagulation disorders. Usually, the clinical signs of estrogen related behavior and the results of vaginal cytology are enough for the differentiation between ORS and other vaginal diseases. The heat behavior is not observed in animals suffering from vaginitis or vaginal tumors, though it can be present in those ones with stump pyometra associated to remnant ovary. However, the presence of $80-90 \%$ of cornified superficial cells is a pathognomonic sign of animals in proestrus/ estrus (SONTAS; GÜRBULAK; EKICI, 2007).

Other clinical conditions, such as hyperactivity of the adrenal gland and estrogen-producing tumors, can also lead to estrus. Although the adrenal gland is able to produce steroid hormones, massive production of estrogen that could produce clinical signs of estrus, in our clinical experience, is very rare in small animals comparing to other species. Concannon, Mccann e Temple (1989) reported that administration of Adrenocorticotropic hormone
$(\mathrm{ACTH})$ in spayed bitches can increase the serum levels of progesterone to $2 \mathrm{ng} / \mathrm{ml}$. The suppression of the adrenal function can be accomplished with the administration of a short-term action glucocorticoid. The clinical signs of estrus usually disappear within 3-5 days of corticoid therapy .

Ovarian tumors may lead to symptoms resembling estrogenic stimulation in bitches (i.e., vaginal bleeding, attraction by male canines) (LOPEZ; MACEDO, 2004). When resection of the ovary is not completely achieved in spayed females, the remnant ovarian tissue may revascularize, become functional and in same cases, develop malignant neoplasms (CARPENTER; ANDREWS; HOLZWORTH, 1987). It has been reported a case of a spayed cat presenting recurrent estrus, that was caused by a granulosa cell tumor (MANDIGERS; NELL, 2001). Granulosa cell tumors emerge from atretic follicles and in $33 \%$ of the patients hyperestrogenism was detected (MCENTEE, 1990, SOUZA et al., 2005). Interstitial cell tumors have also been related to clinical signs of estrogenism (MCENTEE, 1990). Ovarian tumors may vary in diameter from 6 to $30 \mathrm{~cm}$ and metastasis may occur in $10-20 \%$ of the cases of granulosa cell tumors and disgerminoma (MCENTEE, 1990). The detection of soft tissue mass resembling ovarian tumor is 
difficult by abdominal palpation, ultrasonography or abdominal radiography, reason why the diagnosis of remnant ovarian tissue neoplasia should be properly achieved only after resection of the tissue and its histopathological study (MCENTEE, 1990, PERKINS; FRAZER, 1995). The case of two spayed bitches with ORS and ovarian tumors has been reported (SIVACOLUNDHU; O'HARA; READ, 2001). In these animals, the interval between the surgical spay and the manifestation of ORS-related symptoms was six and nine years, respectively. After the exeresis of the ovarian tissue, granulosa cell tumors were confirmed histologically.

\section{Conservative treatment/management of ors}

Conservative treatment of ORS with drugs is not recommended by clinicians. Drugs can inhibit the signs of ORS but do not solve the problem and present adverse side effects. However, this possibility should be considered when pet owners refuse to submit their animal to an exploratory surgery, due to the probability of unsuccessful localization and exeresis of the ovarian tissue in a new surgical intervention, that can derive in unnecessary expenses and surgical risks (SANGSTER, 2005). Generally, the conservative treatment is based on the use of exogenous steroids to inhibit estrus. In addition new therapies consisting of gonadotropin releasing hormone (GnRH) agonists, GnRH antagonists, immunization against $\mathrm{GnRH}, \mathrm{LH}$ or the $\mathrm{LH}$ receptor and the use of GnRH- toxin conjugates are under investigation.

Exogenous steroids, such as progestins and androgens, suppress estrus via inhibition of pituitary gonadotropin secretion and release (NEUMANN et al., 1976). Among progestins, megestrol acetate, medroxyprogesterone acetate (MPA), proligestone are used. Megestrol acetate is a synthetic progestin that has been widely used for temporally estrus suppression in female pets. It can be administered orally at a daily dose of $2.2 \mathrm{mg} / \mathrm{kg}$ for 8 days, beginning at the early proestrus or as soon as sexual behaviour signs are suspected (BURKE; REYNOLDS, 1975, FELDMAN; NELSON, 2004). In the queen, megestrol acetate is mainly used orally at a dose $5 \mathrm{mg} / \mathrm{cat}$ for 3 days followed by 2.5 to $5 \mathrm{mg} /$ week for 10 weeks (BURKE, 1982; FELDMAN; NELSON, 2004). This treatment has suppressed estrus in $92 \%$ of the patients but, despite its efficiency, reported side effects in the bitch and queen include: change in temperament, increasing appetite leading to weight gain, growth hormone secretion with resultant signs of acromegalia and insulin resistance (BURKE; REYNOLDS, 1975; NEUMANN et al., 1976; EIGENMANN, 1986), mammary hyperplasia and/or neoplasms (SOREMNO et al., 2000; STONE, 2003), stump pyometra (HAGMAN, 2004), reversible transitory hypoadrenocorticism (VAN DEN BROEK; O'FARRELL, 1994) as well as other clinical signs consistent with adrenocortical suppression (i.e. alopecia, hair discoloration, thinning of the skin and mobilization of subcutaneous fat) (KUTZLER; WOODS, 2006). Because megestrol is metabolised in the liver, its use is especially discouraged in animals with liver dysfunction (HENIK et al., 1985).

Proligestone (14 $\alpha, \quad 17 \alpha$-propylidene-dioxy progesterone) has weaker progestacional activity and less secondary effects than megestrol (OS; OLDENKAMP, 1978). It is used to prevent, delay or suppress estrus at an initial dose of $10-30 \mathrm{mg} / \mathrm{kg}$ subcutaneously, with repeated administration 3 and 7 months later (EVANS; SUTTON, 1989). In queens $100 \mathrm{mg}$ of proligestone applied subcutaneously has been shown to cause estrus suppression for 6.5 months (HENIK; OLSON; ROSYCHUK, 1985; EVANS; SUTTON, 1989).

Androgens have also been used for estrus suppression in the bitch. Mibolerone is a synthetic androgen used at various doses depending of the body weight of the bitch. For bitches $0.5 \mathrm{~kg}$ up to $12 \mathrm{~kg}$ the dose is $30 \mu \mathrm{g} / \mathrm{day}$, for a weight between 12 and 23 the dose is $60 \mu \mathrm{g} / \mathrm{day}$, for a weight between 23 and $43 \mathrm{~kg}$ the dose is $120 \mu \mathrm{g} /$ day and for bitches weighting more than $45 \mathrm{~kg}$ the dose is 
$180 \mu \mathrm{g} /$ day (FELDMAN; NELSON, 2004). The inconvenience of this treatment is that it should start 30 days before the beginning of proestrus, which is difficult to predict in animals that present ORS. Long-term treatment with mibolerone may lead to problems such as virilization, clitoral hyperplasia, behavioral alterations, vaginal secretions, vaginitis, urinary incontinence and hepatic dysfunction (EVANS; SUTTON, 1989; FELDMAN; NELSON, 2004). Mibolerone should not be administrated to Bedlington Terrries or queens due to an increased risk of hepatic dysfunction (MUNSON et al., 2001; KUTZLER; WOOD, 2006).

Besides exogenous steroids, GnRH agonists can also be used to suppress estrus. Sustained exposure to GnRH induces GnRH receptor downregulation, internalization and signal uncoupling that leads to the interruption of pulsatile secretion of gonadotropins, the inhibition of follicular development and consequently, the reduction of the secretion of estrogen (ROMAGNOLI, 2004). Subcutaneous administration of nafarelin (16$32 \mu \mathrm{g}$ /day) via an implanted osmotic pump or by daily injections, delays puberty and estrus in female dogs (RUBION et al., 2004; KUTZLER; WOOD, 2006). After cessation of treatment, cycling bitches have returned to estrus between 2 and 18 weeks (RUBION et al., 2004; KUTZLER; WOOD, 2006). Subcutaneous administration of deslorelin via a slow-releasing implant suppressed estrus for up to 27 months in female dogs (TRIGG et al., 2001). Although suitable, GnRH agonists lead to some side effects, such as the initial gonadotropin stimulatory response that leads to the induction of estrus in anestrous bitches within 1-4 weeks following initiation of the treatment (RUBION et al., 2004).

In the queen, the use of GnRH analogues for suppression of estrus is under investigation. A preliminary study has reported that $6 \mathrm{mg}$ deslorelin implants suppressed estradiol secretion for periods of at least 14 months in $80 \%$ of the animals (MUNSON et al., 2001). This study also described some side effects, such as a local reaction that occasionally appeared at the site of the implant insertion in some of the animals and an initial stimulatory gonadotropin response that consisted of an estrus-like increase in estradiol concentrations.

Other possibility of inhibiting estrus behaviour in ORS animals is by using GnRH antagonist. The rationale of this treatment is to block the $\mathrm{GnRH}$ receptors by using $\mathrm{GnRH}$ antagonists with longer half life and higher affinity for the receptor than the endogenous $\mathrm{GnRH}$, inhibiting its action and thus suppressing gonadotropin release. A preliminary study has reported that the subcutaneous administration of acycline at $110 \mu \mathrm{g} /$ $\mathrm{kg}$ within the first 3 days of proestrus resulted in a short, anovulatory estrus with return to proestrus within 3 weeks of treatment (LOPEZ; MACEDO, 2004; HERBERT; TRIGG, 2005). The use of GnRH antagonists in pet animals is promising. Their effects are immediate and they do not induce the initial stimulatory gonadotropin releasing effect of GnRH agonists, but the high dose required and the failure to develop an efficient and controlled delivery system may reduce it practical approach (HERBERT; TRIGG, 2005; KUTZLER; WOOD, 2006).

Other option for the clinical treatment of ORS is immunocastration or immunosterilization. The aim of this therapy is to inhibit estrus by inducing the production of antibodies against $\mathrm{GnRH}, \mathrm{LH}$ or their receptor in the pet. Development of a GnRH vaccine is problematic because $\mathrm{GnRH}$ is a well preserved peptide among species, it has only ten amino acids and it is not naturally immunogenic. Several studies carried out with GnRH molecules conjugated to various antigens to mobilize T-helper cells have shown promising results in the dog, but its effects on the bitch or in the queen have not been studied in detail (LADD et al., 1994; FERRO et al., 2004; JUNG et al., 2005; KUTZLER; WOOD, 2006).

Immunocontraception targeting $\mathrm{LH}$ and its receptor has been successful in domestic carnivores and may be an attractive alternative for the clinical 
management of ORS (SAXENA et al., 2002). Vaccination of the bitch and queen with a bovine $\mathrm{LH}$ receptor vaccine resulted in estrus suppression for up to 11 months, with return to normal physiologic reproductive state after the antibody titers declined (SAXENA et al., 2002, SABEUR et al., 2003). Further development of GnRH or gonadotropin vaccines has been hampered by the need of applying multiple boosters to ensure the production and maintenance of high antibody titers. Another drawback is the highly variable response between individual animals as well as the high cost of the antigen due to the low efficiency of conjugation (KUTZLER; WOOD, 2006). In general, GnRH agonists have shown more efficiency and fewer side effects than immunization against GnRH or gonadotropins (HERBERT; TRIGG, 2005).

Immunocontraception toxins conjugated to GnRH can be used to disrupt the hypothalamic - pituitary-gonadal axis. The internalization of the GnRH receptors following binding of $\mathrm{GnRH}$ conjugated to the toxin provides a selective way to disrupt the pituitary gonadotrops by damaging them in sufficient number to cease the reproductive function (SABEUR et al., 2003). Although the GnRH-toxin technology provides an interesting alternative to surgical sterilization its use in pets requires further investigation (HERBERT; TRIGG, 2005).

\section{Surgical treatment}

The surgical management is the treatment of choice for ORS. It consists basically of a new laparotomic or laparoscopic approach for localization and resection of the remnant ovary. The determination of the right moment for the execution of the surgical procedure is one of the most important considerations for a successful intervention. The surgical approach should be performed preferentially in diestrus, because the presence of follicles or corpus luteum and collateral vascularization provide better visualization and location of the ovarian tissue. Some authors have suggested that the surgical procedure should be performed between 15 and 60 days after the perception of attraction of males (WALLACE, 1991; HARVEY, 1998). It is not recommended to carry out the surgical procedure during anestrous since the ovarian tissue is atrophied, ischemic and difficult to locate or differentiate from other intraperitoneal structures (WALLACE, 1991; SONTAS; GÜRBULAK; EKICI, 2007). It has to be taken into account that even when laparotomy is executed during estrus or diestrus, finding the remnant ovarian tissue may be still difficult. Therefore, referral to a specialist in small animal soft tissue surgery is recommended to increase the chances of success (PERKINS; FRAZER, 1995).

The abdominal incision should be performed more cranially than the usual standard for traditional OHE (HOWE, 2006). In order to facilitate the localization of the ovarian pedicles during laparotomic or laparoscopic access, a mild thoracic rotation can be performed (SILVA, 2008). If the exposition of the right ovarian pedicle is desired, the right thoracic limb should be attached to the left one promoting a mild rotation of the thorax to the left side. The same maneuver at the opposite side should be performed for the exposition of the left ovarian pedicle. Additionally, medial traction of the duodenum improves the exposition of the right AVOC. In a similar way, medial traction of the colon enhances the access to the left ovarian pedicle (STONE, 2003). These maneuvers substantially improve the chances of success in the second surgical intervention considering that, in most cases, the remnant ovary tissue is found in their original anatomical location (VAN GOETHEM; SCHAEFERS-OKKENS; KIRPENSTEIJN, 2006), adhered to the mesovarium, near the caudal pole of the kidneys.

During surgery, suspected tissues should be removed, especially those near the AVOCs, taking special care not to damage the ureters. The exceeding uterine stump should also be excised if 
present (HOWE, 2006), as stump piometra (Fig. 2) may also be associated to the ORS in many cases (SONTAS; GÜRBULAK; EKICI, 2007). Ovarian tissues are more likely to be found in one or both ovarian pedicles, although they can also be present on the mesentery, mesometrium or greater omentum. If no ovarian mass is detected, granulomas surrounding the AVOCs, (which may host remnant ovarian tissue), and/or the uterine stump should be excised (FELDMAN; NELSON, 2004; SONTAS; GÜRBULAK; EKICI, 2007). After excision of the remnant ovary, clinical signs may disappear permanently within few days or weeks (WALLACE, 1991).

Figure. 2. Resection of an ovarian remnant in a bitch, accessed by median celiotomy: (A) the ovarian remnant (OV) was adhered to the right ovarian pedicle (ROP) and to the greater omentum (OM). The white silk thread (white arrow) used for the ligature of the ovarian pedicle is seen between the jaws of a Halsted forceps; (B) ovarian remnant after excision. A piece of mesovarium (MO) and greater omentum $(\mathrm{OM})$ is attached to the ovarian tissue.

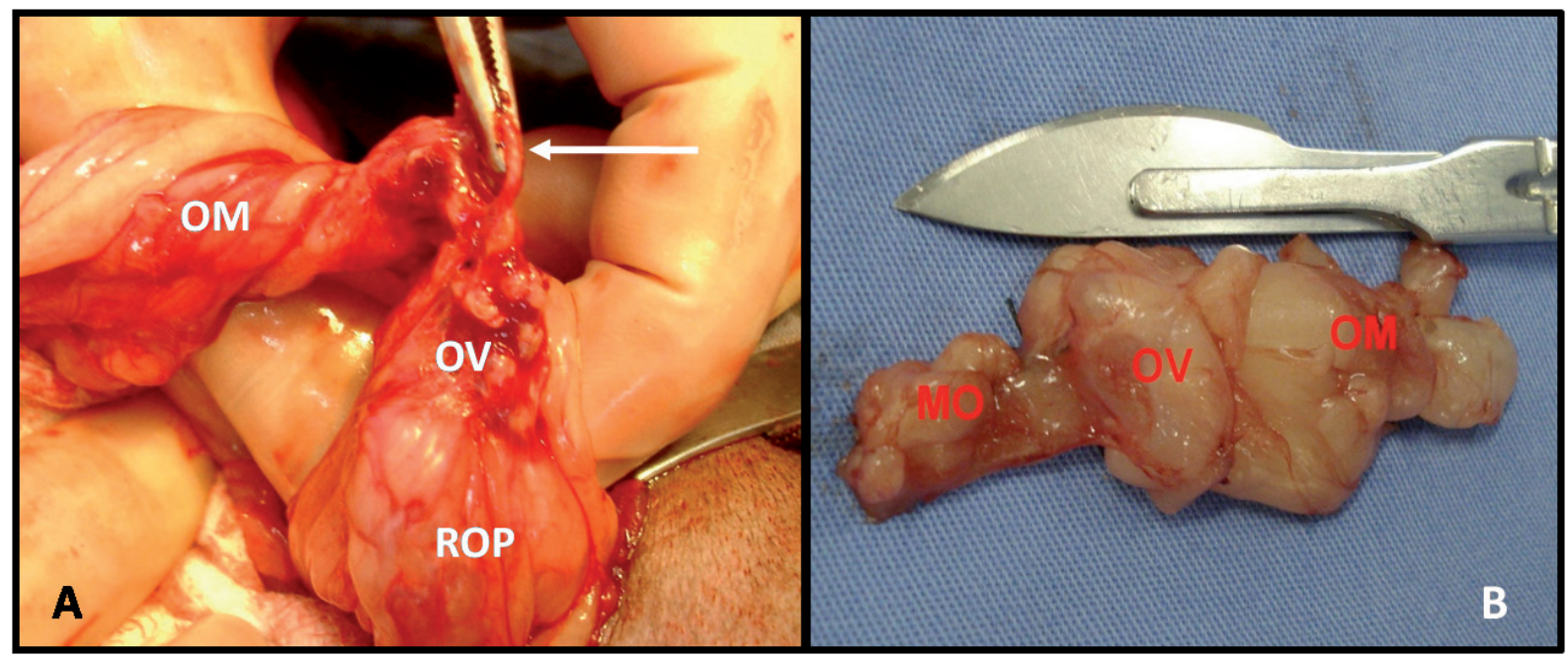

Fonte: VOORWALD, F. A. (2012)

The development of minimally invasive laparoscopic surgery (MILS) can improve the surgical management of ORS. MILS usually results in better surgical recovery and less postoperative pain in companion animals (FREEMAN, 1999, DEVITT; COX; HAILEY, 2005). Two cases of successful laparoscopic resection of remnant ovary in a bitch (BECK et al., 2004) and a queen (BRUN et al., 2006) have been reported (Fig. 3). Video laparoscopy can make easier to excise ovarian remnants. Among the advantages of this surgical procedure over traditional exploratory laparotomy, magnification of the image (i.e., better visualization of intraperitoneal structures), minor surgical trauma, and less hospitalization time, recovery period and postoperative pain, are highlighted (KAMPRATH; POSSOVER; SCHNEIDER, 1997, NEZHAT et al., 2005). When pet owners are not convinced of a new surgery involving an extensive abdominal incision, the use of MILS, with minor incisions, and better and faster recovery become more attractive. In order to perform the laparoscopic treatment of ORS in dogs and cats, only two or three $6 \mathrm{~mm}$ length abdominal incisions are required to ensure an adequate visualization of the peritoneal cavity (BECK et al., 2004, BRUN et al., 2006). 
Figure. 3. Laparoscopic resection of left ovarian remnant in a queen. (A) The ovarian tissue (OV, arrow) was identified adhered to the left mesovarium (MO) and to the omentum (OM). The spleen (BA) is seen. (B) The ovarian mass was grasped and raised. (C) Monopolar coagulation and transaction of the adhesions between the ovarian tissue and the omentum and between the mesovarium (D) and the ovarian remnant was performed.

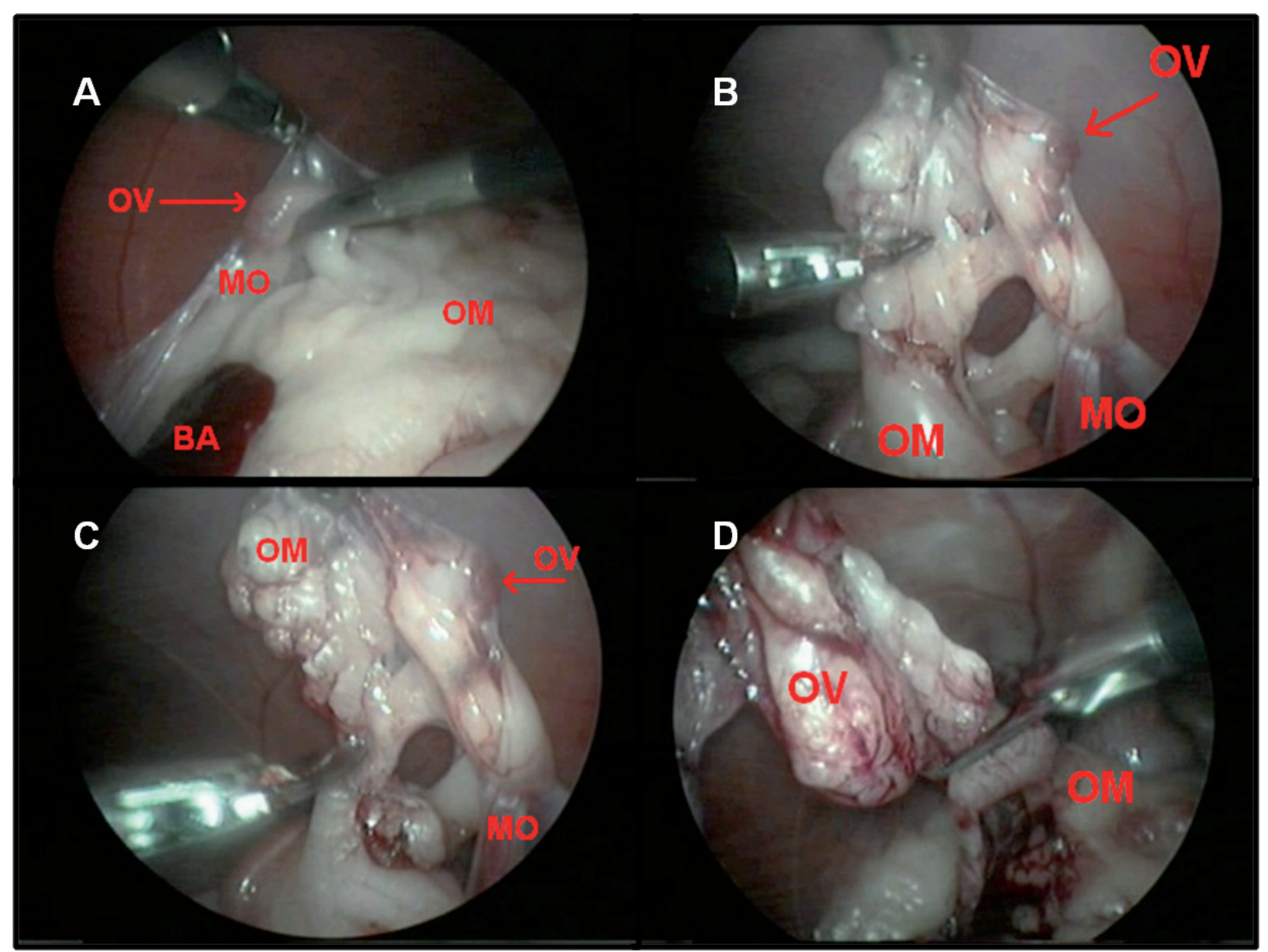

Fonte: VOORWALD, F. A. (2012)

\section{Prophylaxis: preventing ORS}

Some surgical maneuvers should be adopted during surgical spay to improve ovarian pedicle exposition and to avoid the permanence of ovarian tissue within the abdominal cavity. Several surgical techniques have been described for clamping and performing the ligature of the AVOCs and uterine stump in bitches and cats, including single, double and triple transversal clamping (FINGLAND, 1998, STONE, 2003). Independently of the technique employed, it is crucial to visualize the ovary in cats, or to gently grasp the ovary with the thumb and the forefinger in dogs (in this case, the ovary is more difficult to visualize because it is surrounded by the ovarian bursa) for posterior safe pedicular clamping. These simple maneuvers aim to prevent some surgical accidents, such as inclusion of ovarian tissue between the jaws of the haemostatic forceps or in the ligature, which would lead to the adhesion of ovarian tissue to the ovarian pedicle and probably to the development of ORS (HOWE, 2006). The presence of accessory ovarian tissue should not be neglected, especially in cats, where careful inspection and palpation of the ovarian pedicles should be performed during the surgical procedure (MILLER, 1995).

The rupture of the ovarian suspensory ligament is encouraged during surgical spay in bitches, especially when the ovarian pedicles are deeper than the usual. This can be accomplished by grasping the 
proper ligament of the ovary with the thumb and the middle finger, using the forefinger simultaneously to promote gentle caudal traction on the suspensory ligament until its complete rupture, or using a Halsted haemostatic clamps to isolate, clamp and torn the ligament by meticulous traction. Frequently, a "pop" sound is listened when the suspensory ligament of the ovary is ruptured. Additional care should be taken not to dilacerate the ovarian pedicle. Alternatively, the suspensory ligament can also be dissected and sectioned with curved Metzenbaum scissors, only if direct visualization of the ligament is achievable. The rupture of the ovarian suspensory facilitates the exposition, ligation and resection of the ovarian pedicle. If the exposition of the ovarian pedicle remains difficult, cranial advance of the abdominal incision should be performed until proper exposition is reached (HOWE, 2006).

Prepubertal gonadectomy (or early-age gonadectomy) seems a reasonable and an efficient method for preventing ORS, as it is technically easier to perform ovariohysterectomy or ovariectomy in young animals, because the exposition of the ovarian pedicle is somehow simpler. Furthermore, there is no report of ORS in spayed animals younger than four months.

\section{Laparoscopic ovariohysterectomy and} ovariectomy are minimally invasive approaches that may decrease the occurrence of ORS, because they allow adequate isolation and preventive haemostasis of the AVOCs through better visualization. Modern imaging systems enable magnification up to 10-50 times of the periovarian structures. Furthermore, no report of ORS in animals submitted to laparoscopic OHE or OVX has been described (BECK et al., 2004; LOSS et al., 2008).

\section{Conclusions}

Ovarian remnant syndrome is frequently an iatrogenic disturbance in companion animals where a fragment of ovarian tissue is accidentally maintained or dropped within the abdominal cavity. Improper exposition of the ovarian pedicles, specially the right one, has been pointed as the main risk factor.

The main clinical signs of ORS are basically the same signs observed in non-spayed dogs or cats in proestrus/estrus. Although there are many diagnostic tools to confirm ORS in small animals, vaginal smear evaluation provides the best cost/ benefit. However, serum estrogen and progesterone dosing or even challenging test with hCG or GnRH may be necessary to confirm the diagnosis.

Clinical management of ORS is usually both controversial and expensive, what makes surgery the treatment of choice. The surgical approach should be performed when the animal is in diestrus. In order to improve the chances of finding the remnant ovary, laparoscopy may be suitable for the surgical management of ORS, since it is minimally invasive and amplifies the image of intraperitoneal structures.

Furthermore, preventing ORS is always the best alternative, which can be achieved with the use of careful and meticulous surgical maneuvers during ovariohysterectomy or ovariectomy.

\section{References}

BECK, C. A. C.; PIPPI, N. L.; RAISER, A. G.; BRUN, M. V.; GONÇALVES, G. F.; PORTELlA, L. C. V.; LEME, M. C.; STEDILE, R. Laparoscopic ovariectomy in a bitch owning remnant ovaries: case report. MEDVEP, Curitiba, v. 2, n. 5, p. 15-19, 2004.

BRUN, M. V.; OLIVEIRA, R. P.; BARCELLOS, H. H. A.; BECK, C. A. C.; PIPPI, N. L.; MESSINA, S. A.; GONÇALVES, H. R.; GUIZZO JÚNIOR, N. Treatment of different presentations of pyometra in dogs by laparoscopy or laparoscopic-assisted approach. MEDVEP, Curitiba, v. 4, n. 11, p. 26-33, 2006.

BURKE ,T.; REYNOLDS, J. R. H. Megestrol acetate for estrus postponement in the bitch. Journal American Veterinary Medicine Association, Schaumburg, v. 167, n. 4, p. 285-287, 1975.

BURKE, T. J. Pharmacologic control of estrus in bitch and queen. Veterinary Clinics North America Small Animal Practice, Philadelphia, v. 12, n. 1, p. 79-84, 1982. 
CARPENTER, J. L.; ANDREWS, L. K.; HOLZWORTH, J. Tumors and tumor- like lesions. In: HOLZWORTH, J. (Ed.). Diseases of the cat: medicine and surgery. Philadelphia: W.B. Saunders, 1987, p. 406-596.

CONCANNON, P. W. Contraception in the dog. The Veterinary Annual, Oxford, v. 35, p. 177-187, 1995.

CONCANNON, P. W.; MCCANN, J. P.; TEMPLE, M. Biology and endocrinology of ovulation, pregnancy and parturition in the dog. Journal Reproduction and Fertility Supplement, Cambridge, v. 39, p. 3-25, 1989.

CONCANNON, P. W.; COWAN, R.; HANSEL, W. LH release in ovariectomized dogs in response to estrogen withdrawal and its facilitation by progesterone. Biology of Reproduction, Madison, v. 20, n. 3, p. 523-531, 1979.

CONCANNON, P. W.; HANSEL, W.; VISEK, W. The ovarian cycle of the bitch: plasma estrogen, LH and progesterone. Biology of Reproduction, Madison, v. 13, n. 1, p. 112-121, 1975.

CONCANNON, P. W.; MEYERS-WALLEN, V. N. Current and proposed methods for contraception and termination of pregnancy in $\operatorname{dog}$ and cats. Journal American Veterinary Medicine Association, Schaumburg, v. 198, n. 7, p. 1214-1225, 1991.

COOLMAN, B. R.; MARRETTA, S. M.; DUDLEY, M. B.; AVERILL, S. M. Partial colonic obstruction following ovariohysterectomy: a report of three cases. Journal of the American Animal Hospital Association, Denver, v. 35, n. 2, p. 169-172, 1999.

DAVIES, N. Complications of ovarian autotransplantation in bitches: an update. Journal of the South African Veterinary Association, Pretoria, v. 61, n. 4, p. 171, 1990.

DENARDO, G. A.; BECKER, K.; BROWN, N. O.; DOBBINS, S. Ovarian remnant syndrome: revascularization of free-floating ovarian tissue in the feline abdominal cavity. Journal of the American Animal Hospital Association, Denver, v. 37, n. 3, p. 290-296, 2001.

DEVITT, C. M.; COX, R. E.; HAILEY, J. J. Duration, complications, stress, and pain of open ovariohysterectomy versus a simple method of laparoscopic-assisted ovariohysterectomy in dogs. Journal of the American Animal Hospital Association, Denver, v. 227, n. 6, p. 921-927, 2005.

DROLLETTE, C. M.; BADAWY, S. Pathophysiology of pelvic adhesions modern trends in preventing infertility. The Journal of Reprodctive Medicine, St. Louis v. 37, n. 2, p. 107-121, 1992.

EIGENMANN, J. Growth hormone and insulin-like growth factor in the dog: clinical and experimental studies. Schweizer Archiv für Tierheilkunde, Bern, v. 128, n. 2, p. 57-78, 1986.

ENGLAND, G. C. W. Confirmation of ovarian remnant syndrome in the queen using hCG administration. The Veterinary Record, London, v. 141, n. 12, p. 309-310, 1997.

EVANS, J. M.; SUTTON, D. J. The use of hormones, especially progestagens, to control oestrus in bitches. Journal Reproduction and Fertility Supplement, Cambridge, v. 39, p. 163-173, 1989.

FELDMAN, E. C.; NELSON, R. W. Ovarian remnant syndrome. In: FELDMAN, E. C.; NELSON, R. W. (Ed.). Canine and feline endocrinology and reproduction. $3^{\text {rd }}$ ed. Philadelphia: W.B. Saunders, 2004. p. 892-893.

FERRO,V.; KHAN, M.A.H.;MCADAM,D.;COLSTON, A.; AUGHEY, E.; MULLEN, A.; WATERSTON, M.; HARVEY, M. J. A. Efficacy of an anti-fertility vaccine based on mammalian gonadotrophin releasing hormone (GnRH-I): a histological comparison in male animals. Veterinary Immunology and Immunopathology, Philadelphia, v. 101, n. 1/2, p. 73-86, 2004.

FINGLAND, R. B. Ovariohysterectomy. In: BOJRAB, M. J. (Ed.). Current techniques in small animal surgery. $4^{\text {th }}$ ed. Baltimore: Williams \& Wilkins, 1998. p. 489-496.

FOSSUM, T. W. Small animal surgery. $3^{\text {rd }}$ ed. St. Louis: Elsevier B.V., 2007. 1728 p.

FREEMAN, L. J. Veterinary endosurgery. Saint Louis: Mosby, 1999. 276 p.

GADELHA, C. R. F.; RIBEIRO, A. P. C.; APPARÍCIO, M. F.; COVIZZI, G. J.; VICENTE W. R. R. Acquired vesicovaginal fistula secondary to ovariohysterectomy in a bitch: a case report. Arquivo Brasileiro de Medicina Veterinária e Zootecnia, Belo Horizonte, v. 56, n. 2, p. 183-186, 2004.

HAGMAN, R. New aspects of canine pyometra studies on epidemiology and pathogenesis. 2004. Tesis (Doctorate in Veterinary Medicine) - Department of Small Animal Clinical Science. Swedish University of Agricultural Science. Uppsala, Sweden.

HARVEY, M. Conditions of the non-pregnant female. In: SIMPSON, G. M.; ENGLAND, G. C. W.; HARVEY, M. (Ed.). BSAVA Manual of small animal reproduction and neonatology. Shurdington: Cheltenham, 1998. p. 35-53.

HEFFELFINGER, D. J. Ovarian remnant in a 2-year-old queen. The Canadian Veterinary Journal, Ottawa, v. 47, n. 2, p. 165-167, 2006.

HENIK, R.; OLSON, P.; ROSYCHUK, R. Progestogen therapy in cats. Compendium on Continuing Education 
for the Practicing Veterinarian, Yardley, v. 7, n. 2, p. 132137, 1985.

HERBERT, C.; TRIGG, T. Applications of GnRH in the control and management of fertility in female animals. Animal Reproduction Science, Philadelphia, v. 88, n. 1/2, p. 141-153, 2005.

HOLT, P. E. Uninary incontinence in the bitch due to sphincter mechanism incompetence: surgical treatment. Journal of Small Animal Practice, London, London, v. 26, n. 5, p. 237-46, 1985.

HOLT, P. E.; BOHANNON, J.; DAY, M. J. Vaginoperitoneal fistula after ovariohysterectomy in three bitches. Journal of Small Animal Practice, London, v. 47, n. 12, p. 744-746, 2006.

HOWE, L. M. Surgical methods of contraception and sterilization. Theriogenology, Philadelphia, v. 66, n. 3, p. 500-509, 2006.

IGUCHIL, T. Involvement of fas in regression of vaginal epithelia after ovariectomy and during an estrous cycle. The Embo Journal, London, v. 15, n. 12, p. 211-215, 1996.

JOHNSTON, S. D.; KUSTRITZ, M. V. R.; OLSON, P. N. S. Ovarian remnant syndrome. In: JOHNSTON, S. D.; KUSTRITZ, M. V. R.; OLSON, P. N. S. (Ed.). Canine and feline theriogenology. Philadelphia: W.B. Saunders, 2001. p. 199-200.

JUNG, M. J.; MOON, Y. C.; CHO, I. H.; YEH, J. Y.; KIM, S. E.; CHANG, W. S.; PARK, S. Y.; SONG, C. S.; KIM, H. Y.; PARK, K. K. Induction of castration by immunization of male dogs with recombinant gonadotropin-releasing hormone (GnRH)-canine distemper virus (CDV) T helper cell epitope p35. Journal of Veterinary Science, Seoul, v. 6, n. 1, p. 21-24, 2005.

KAMPRATH, S.; POSSOVER, M.; SCHNEIDER, A. Description of a laparoscopic technique for treating patients with ovarian remnant syndrome. Fertility and Sterility, Birmingham, v. 68, n. 4, p. 663-667, 1997.

KUTZLER, M.; WOOD, A. Non-surgical methods of contraception and sterilization. Theriogenology, Philadelphia, v. 66, n. 3, p. 514-525, 2006.

LADD, A.; TSONG, Y.; WALFIELD, A.; THAU, R. Development of an antifertility vaccine for pets based on active immunization against luteinizing hormonereleasing hormone. Biology of Reproduction, Madison, v. 51, n. 6, p. 1076-1083, 1994.

LOPEZ, M. D.; MACEDO, L. P. Síndrome del ovario remanente en perras y gatas. In: GOBELLO, C. (Ed.). Temas de reproducción de caninos y felinos por autores latinoamericanos. Buenos Aires: Gráfica Latina, 2004. p. 61-64.
LOSS, F. R.; COLOMÉ, L. M.; BRUN, M. V.; VILARINHO, R. C.; GUEDES, R. L. Ovarian remnant syndrome in a female canine. In: CONBRAVET, 35. 2008, Gramado. Proceedings... SOVERGS: Gramado, RS, 2008. CD-ROM.

MACHADO, R.; BERGAMASCHI, M. A.; BARBOSA, R. T.; DE OLIVEIRA, C. A.; BINELLI, M. Ovarian function in Nelore (Bos taurus indicus) cows after post-ovulation hormonal treatments. Theriogenology, Philadelphia, v. 69, n. 7, p. 798-804, 2008.

MANDIGERS, R.; NELL, T. Treatment of bitches with acquired urinary incontinence with oestriol. The Veterinary Record, London, v. 149, n. 25, p. 764-767, 2001.

MCENTEE, K. Congenital anomalies. In: (Ed.). Reproductive pathology of domestic mammals. San Diego: Califórnia Academic Press Inc, 1990. p. 36-41.

MICHELL, A. Longevity of british breeds of dog and its relationships with sex, size, cardiovascular variables and disease. The Veterinary Record, London, v. 145, n. 22, p. 625-629, 1999.

MILLER, D. M. Ovarian remnant syndrome in dogs and cats: 46 cases (1988-1992). Journal of Veterinary Diagnostic Investigation, Davis, v. 7, p. 572-574, 1995.

MILLS, J. N.; VALLI, V.; LUMSDEN, J. Cyclical changes of vaginal cytology in the cat. Canadian Veterinary Journal, Ottawa, v. 20, n. 4, p. 95-101, 1979.

MOORE, G. E.; BURKMAN, K. D.; CARTER, M. $\mathrm{N}$; PETERSON, M. R. Causes of death or reasons for euthanasia in military working dogs: 927 cases (19931996). Journal of the American Animal Hospital Association, Denver, v. 219, n. 2, p. 209-214, 2001.

MUNSON, L.; BAUMAN, J. E.; ASA, C. S.; JOCHLE, W.; TRIGG, T. E. Efficacy of the GnRH analogue deslorelin for suppression of oestrous cycles in cats. Journal Reproduction and Fertility Supplement, Cambridge, v. 57, p. 269-273, 2001.

NELSON, R. W.; COUTO, C. G. Disorders of the estrous cycle. $3^{\text {rd }}$. ed. In: (Ed.). Small animal internal medicine. Missouri: Mosby, 2003. cap. 56, p. 851-869.

NEUMANN, F.; DIALLO, F.; HASAN, S.; SCHENCK, B.; TRAORE, I. The influence of pharmaceutical compounds on male fertility. Andrologia, Giessen, v. 8, n. 3, p. 203-235, 1976.

NEZHAT, C.; KEARNEY, S.; MALIK, S.; NEZHAT, C.; NEZHAT, F. Laparoscopic management of ovarian remnant. Fertility and Sterility, Birmingham, v. 83. n. 4, p. 973-978, 2005. 
OKKENS, A. C.; DIELEMAN, S. J.; VAN DER GAAG, I. Gynaecologische complicaties na ovario-hysterectomie bij de hond ten gevolge van: 1. Het incompleet verwijderen van de ovaria. 2 . Een ontsteking van uteruscervixstomp. Tijdschrift voor Diergeneeskunde, Houten, v. 106, n. 22, p. 1142-1158, 1981.

OS, J.; OLDENKAMP, E. Oestrus control in bitches with proligestone, a new progestational steroid. Journal of Small Animal Practice, London, v. 19, n. 1/12, p. 521529, 1978.

OURSLER, M.; LANDERS, J.; RIGGS, B; SPELSBERG, T. Oestrogen effects on osteoblasts and osteoclasts. Annals of Medicine, Philadelphia, v. 25, n. 4, p. 361-371, 1993.

PEARSON, H. The complications of ovariohisterectomy in the bitch. Journal of Small Animal Practice, London, v. 14, n. 5 , p. $257-266,1973$.

PERKINS, N. R.; FRAZER, G. S. Ovarian remnant syndrome in a toy poodle: a case report. Theriogenology, Philadelphia, v. 44, n. 3, p. 307-12, 1995.

PETTIT, P. D.; LEE, R. A. Ovarian remnant syndrome: diagnostic dilemma and surgical challenge. Obstetrics and Gynecology, Washington, v. 71, n. 4, p. 580-583, 1988.

PINEDA, M.; DOOLEY, M. P. McDonald's veterinary endocrinology and reproduction. $5^{\text {th }}$ ed. Ame: Iowa State Press. 2003. 573 p.

PRATS, A. E. Ovarian remnant syndrome in the queen. EVSSAR Newsletter, London, v. 4, n. 1, p. 5-8, 2001.

PRICE, F.; EDWARDS, R.; BUCHSBAUM, H. Ovary remnant syndrome: difficulties in diagnosis and management. Obstetrical and Gynecological Survey, Philadelphia, v. 45, n. 3, p. 151-156, 1990.

RAGNI, R. A. Pyometra in a bitch following unusual sterilization. Journal of Small Animal Practice, London, v. 46, n. 1, p. 39-40, 2005.

REECE, W. O.; SWENSON, M. J.; REECE, W. Duke's physiology of domestic animals. $12^{\text {th }}$ ed. New York: Comstock Publishing, 2004. 999 p.

RENAULD, A.; LAWZEWITSCH, I.; PÉREZ, R. L.; SVERDLIK, R.; AGÜERO, A.; FOGLIA, V. G.; RODRÍGUEZ, R. R. Effect of estrogens on blood sugar, serum insulin and serum free fatty acids, and pancreas cytology in female dogs. Acta Diabetologica, Heidelberg, v. 20, n. 1, p. $47-56,1984$.

ROMAGNOLI, S. Ovarian remnant syndrome. In: EVSSAR CONGRESS, 4., 2004, Barcelona. Proceedings... Barcelona: [s.n], 2004. p. 239-241. (Abstract).
RUBION, S.; DESMOULINS, P. O.; RIVIERE-GODET, E. Treatment with a subcutaneous GnRH agonist prevents puberty in bitches. In: INTERNATIONAL SYMPOSIUM ON CANINE AND FELINE REPRODUCTION, 5., 2004, São Paulo. Proceedings... São Paulo: FMVZ, 2004. p. 56-58. (Abstract).

SABEUR, K.; BALL, B.; NETT, T.; BALL, H.; LIU, I. Effect of GnRH conjugated to pokeweed antiviral protein on reproductive function in adult male dogs. Reproduction, Bristol, v. 125, p. 801-806, 2003.

SANGSTER, C. Ovarian remnant syndrome in a 4-yearold bitch. The Canadian Veterinary Journal, Ottawa, v. 46, n. 1, p. 62-64, 2005.

SAXENA, B. B.; CLAVIO, A.; SINGH, M.; RATHNAM, P.; BUKHAROVICH, Y.; REIMERS JUNIOR, T.; SAXENA, A.; PERKINS, S. Modulation of ovarian function in female dogs immunized with bovine luteinizing hormone receptor. Reproduction in Domestic Animals, Berlin, v. 37, n. 1, p. 9-17, 2002.

SHEMWELL, R.; WEED, J. Ovarian remnant syndrome. Obstetrics and Gynecology, Washington, v. 36, n. 2, p. 299-303, 1970

SHILLE, V.; OLSON, P. Dynamic testing in reproductive endocrinology. In: BONAGURA, J. D. (Ed.). Kirk's current veterinary therapy $X$ : small animal practice. Philadelphia: WB Saunders, 1989. p. 1282-1288.

SILVA, M. A. M. Laparoscopic evaluation of postoperative intraperitoneal adhesions in a dog model: use of two doses of methylene blue $1 \%$ solution on the prophylaxis. 2008. Tesis (Masters Degree in Animal Science) - Veterinary School. Federal University of Goiás, Goiânia.

SIVACOLUNDHU, R. K.; O'HARA, A. J.; READ, R. A. Granulosa cell tumor in two spayed bitches. Australian Veterinary Journal, St Leonards NSW, v. 79, n. 3, p. 173176, 2001.

SONTAS, B. H.; GÜRBULAK, K.; EKICI, H. Ovarian remnant syndrome in the bitch: a literature review. Archivo de Medicina Veterinaria, Valdivia, v. 39, n. 2, p. 99-104, 2007.

SOREMNO, K. U.; SHOFER, F. S.; GOLDSCHMIDT, M. H. Effect of spaying and timing of spaying on survival of dogs with mammary carcinoma. Journal of Veterinary Internal Medicine, Malden, v. 14, n. 3, p. 266-270, 2000.

SOUZA, H. J. M.; AMORIM, F. V., JAFFÉ, E.; GORGOZINHO, K. B.; CALIXTO, R. S.; SILVA, J. G.; TOLEDO-PIZA, E. Thymoma and granulosa cell tumor in cat. Acta Scientiae Veterinariae, Porto Alegre, v. 33, n. 2, p. 211-217, 2005. 
STONE, E. A. Ovary and uterus. In: SLATTER, D. (Ed.). Textbook of small animal surgery. $3^{\text {rd }}$ ed. New York: Elsevier Science. 2003, p. 1487-1496.

SUZUKI, T.; NAKAMURA, Y.; MORIYA, T.; SASANO, $\mathrm{H}$. Effects of steroid hormones on vascular functions. Microscopy Research and Technique, Malden, v. 60, n. 1, p. 76-84, 2003.

TEMIZ, M.; ASLAN, A.; GUNGOREN, A.; DINER, G.; KARAZINCIR, S. A giant serous cystadenoma developing in an accessory ovary. Archives of gynecology and obstetrics, Heidelberg, v. 278, n. 2, p. 153-155, 2008.

TRIGG, T. E.; WRIGHT, P. J.; ARMOUR, A. F.; WILLIAMSON, P. E.; JUNAIDI, A.; MARTIN, G. B.; DOYLE, A. G.; WALSH, J. Use of a GnRH analogue implant to produce reversible long-term suppression of reproductive function in male and female domestic dogs. Journal Reproduction and Fertility Supplement, Cambridge, v. 57, p. 255-261, 2001.

VALLE, G. R.; MARQUES JUNIOR, A. P. Endocrinopathology and hormonal therapy of the estral cycle of the bitch. Caderno Técnico de Veterinária e Zootecnia, Belo Horizonte, v. 30, p. 49-74, 1999.
VAN DEN BROEK, A. H. M.; O'FARRELL, V. Suppression of adrenocortical function in dogs receiving therapeutic doses of megestrol acetate. Journal of Small Animal Practice, London, v. 35, n. 6, p. 285-288, 1994.

VAN GOETHEM, V.; SCHAEFERS-OKKENS, A.; KIRPENSTEIJN, J. Making a rational choice between ovariectomy and ovariohysterectomy in the dog: a discussion of the benefits of either technique. Veterinary Surgery, Malden, v. 35, n. 2, p. 136-143, 2006.

VAN HAAFTEN, B.; BEVERS, M. M.; VAN DEN BROM, W. E.; OKKENS, A. C.; VAN SLUIJS, F. J.; WILLEMSE, A. H.; DIELEMAN, S. J. Increasing sensitivity of the pituitary to GnRH from early to late anoestrus in the beagle bitch. Journal of Reproduction and Fertility, Bristol, v. 101, n. 1, p. 221-225, 1994.

WALLACE, M. S. The ovarian remnant syndrome in the bitch and queen. Veterinary Clinics North America Small Animal Practice, Philadelphia, v. 21, n. 3, p. 501-507, 1991.

WEBB, M. Ovarian remnant syndrome. Australian and New Zealand Journal of Obstetrics Gynaecology, Victoria, v. 29, n. 4, p. 433-435, 1989. 